\title{
THE HISTORICAL BACKGROUND OF CONVULSIONS IN CHILDHOOD
}

\author{
BY \\ ROBERT A. SHANKS, M.B., M.R.C.P., F.R.F.P.S. \\ (From the Department of Child Health, University of Glasgow)
}

Convulsions in childhood must be as old as mankind, and it woukd be remarkable if so striking and terrifying an affliction had not received attention of one kind or another throughout the ages. In so far as the attitude of a community to a convulsion is merely a reflection of its attitude to medicine and an indication of its scientific and ethical background, the history of convulsions can only be in essence the history of medicine or, as we are only concerned here with children, of paediatrics. It may however be of some interest to trace briefly the evolution of the present-day conception of convulsions in childhood against the historical background.

\section{Egypt, Babylon, and India}

Although the civilizations of Egypt and Babylon, and Brahminical medicine in India appear to have had more or less enlightened views on the upbringing of children, little can be discovered of their precise attitude to convulsions. It is nevertheless likely that they all shared to some extent the view that a convulsion was due to direct divine intervention or demoniacal possession, a view that lingers even to-day in the words 'epilepsy' and 'seizure.' In ancient Egypt this idea was carried to the extreme of holding all disease and even death to be due to the intervention of external agents (Finlayson): these agents might apparently belong to this or the ' other' world. Thus where the intervention was not obviously of this world, such as an assassin or a falling tree, the physician had the double duty of identifying the offending spirit and thereafter of prescribing the specific treatment. Usually amulets and incantations were regarded as indispensable.

\section{Greece and Rome}

Hippocrates. European medicine begins properly in Greece. The achievements of Athens in the time of Pericles are perhaps the most astonishing in all history. Under the stimulus of victory over the Persians she produced architects, sculptors, and dramatists who remain unsurpassed to the present day. It was at this time that Hippocrates, who was thus a contemporary of Socrates and Plato, lived and taught. Born in this era of untrammelled philosophical speculation, Hippocrates' genius presents a remarkable difference from that of his illustrious contemporaries; for he was the first to treat of medicine as a practical study rather than as a speculative philosophy. His was a method of observation and inductive reasoning so ideally suited to clinical medicine. His writings deal with medicine, surgery, midwifery, embryology, climatology, dietetics, prognostics, and ethics but not specifically with paediatrics. There are, however, numerous pertinent observations in his general writings and in particular his well-known treatise on 'The Sacred Diseases,' or epilepsy. He differentiated between epilepsy and infantile convulsions but the distinction, as we might expect, is not clear.

In the 'Aphorisms' he points out that teething is associated with a number of unhappy affictions including diarrhoea and convulsions, this particularly at the time of the eruption of the canines and in fat constipated infants. Thus originated a belief that over two thousand years of medical progress has not quite eradicated. He also stated that those who were afflicted with the ' falling sickness' before the age of fourteen might become free of it but those who were affected at the age of twenty-five were usually troubled with it to the end. A more important observation on infantile convulsions occurs in 'Prognostics' (Chapter 24) and is worth quoting verbatim (Adams' translation):

'Now in children convulsions occur if there has been acute fever, and if the bowel has not been open, and if they have been sleepless, and if frightened, and if they have been screaming, and if they have changed colour acquiring a greenish or pale or livid or red colour. Convulsions occur most readily from just after birth up to the seventh year. But older children and men are no longer liable to convulsions in fevers, unless some complication with violent and very grave symptoms has arisen, as, for example, happens with acute delirium.' This it will be seen epitomizes fairly well the views on infantile convulsions held until the end of the nineteenth century.

In discussing epilepsy Hippocrates derided and rejected the view of those he termed 'the ancients" that the condition had a supernatural cause as implied by its name. He attributed the disease rather to a specific pathology of the brain, namely, the obstruction by phlegm of the air (sic) in the 
veins of the brain. He also described the aura of true epilepsy.

The importance and greatness of Hippocrates in the history of medicine lies not in the detail of his conclusions, though many of these alone would entitle him to be remembered, but in his method of clinical observation and in his insistence upon the natural origin of disease. It is one of the ironies of history that almost all that was sound in his teaching was forgotten while the dross was handed down reverently through the ages to smother independent thought.

Aristotle. Aristotle, the most versatile of all philosophers, also has a place in the history of convulsions. His father, a court physician, must have spoken often of the great physician, Hippocrates, who died when Aristotle was only fourteen. The medical writings of Aristotle, such as they are, for he was no physician, are at least reminiscent. In Book 7 (which is devoted to Man) of his treatise - On the History of Animals' he writes:

- Children are very subject to spasms especially those that are in good condition and have abundance of rich milk, or whose nurses are fat. Wine is injurious in this complaint, and dark coloured wines more so than those that are pale . . He further points out that these children usually die before the seventh day and it is for this reason that the naming of the child is postponed until then.

Alexander. With Aristotle closes the period of Grecian greatness in philosophy and medicine and with his pupil, Alexander the Great, begins the Hellenistic age famed for its mathematics and science. The brief career of Alexander transformed the Grecian world. In the third century B.C. the Greek city-states came to an abrupt end with the rapid growth of the Macedonian Empire, but meanwhile the Roman Empire was beginning to take form and in the second century B.C. Greek medicine emigrated to Rome. There was no Roman tradition in medicine and indeed; before the Greek influx, Rome had 'got on for 600 years without doctors' according to the elder Pliny.

Celsus. Although medicine was practised almost exclusively by Greeks, the best account of it comes from the pen of a Roman. A. Cornelius Celsus is a subject of much controversy. He is usually said to have lived during the reign of Tiberius Caesar, step-son of Augustus, and to have been a Roman gentleman and not a physician. As to the first, Still would place him earlier, in the reign of Augustus, thus making him a contemporary of Virgil, Livy, and Horace. As to the second, this is most vehemently denied by his translator, Grieve, as also but with more evidence by Still. His are the earliest medical records extant after the Hippocratic writings, to which he shows great deference. Although he is the first to state that children should be treated entirely differently from adults, he left no paediatric writings and as regards convulsions dealt specifically only with epilepsy. His views differ little from those of Hippocrates. He emphasized that convulsions may cease at puberty, and advocated some rather startling remedies including the drinking of the blood of a newly-slain gladiator. Should these remedies be of no avail he tells us, the condition will probably last throughout life. which is not thereby shortened.

Soranus of Ephesus. Soranus of Ephesus, who lived in the second century, is the leading authority upon obstetrics and gynaecology in antiquity. He was also a paediatrician and the latter part of his work upon diseases of women is apparently devoted to infant welfare and the treatment of the commoner diseases of infancy. I have unfortunately been unable to obtain a copy of this, but in the list of contents given by Still there is no mention of convulsions or epilepsy.

Galen. The ancient period closes with the name of the greatest and most influential Greek physician. Galen, who lived from A.D. 131 to 201 , founded a system of physiology, pathology and pharmacy which dominated Europe up to the time of Vesalius in the sixteenth century. At the age of 34 he settled in Rome to become court physician to Marcus Aurelius. He was a prolific writer but included little of paediatrics. In his 'De Sanitute Tuenda' he treats of infant hygiene. There is also a discourse on an epileptic boy, for whom he recommends purgation and squills together with full directions as to diet and physical exercise. In a lesser known work 'On Medical Experience' he exemplifies the importance of sequence in symptomatology thus:

'If, for example, convulsion follows fever, this is a sign of death and if fever follows convulsion, this is a sign of safety.' Galen's importance lies in the wide acceptance which his attitude of mind to natural phenomena commanded. Gone was the clinical observation of Hippocrates, gone was the imaginative freedom of thought, the heritage of the Greeks. For Galen crystallized Greek thought into a rigid system that explained everything, and the ingenuity of physicians of the next fifteen hundred years was exercised in the Procrustean task of fitting observed facts to his principles.

\section{The Empire of Byzantium}

The next six centuries saw the fall of the Western Roman Empire and the establishment of the Byzantine Empire in the east which was to last another thousand years. The degeneration of the Roman Empire into a great unwieldy administrative machine in which nearly every one of education was a civil servant gave it little strength to repel barbarians from the north. Meanwhile the Christian Church was growing rapidly into a vast and inflexible hierarchy and attracted all the outstanding minds to her service. Already torn and buffeted within by theological controversies and obsessed with the problems of heresy, she looked askance at all original thought and laid the foundations for an age of ignorance, superstition, and unspeakable cruelty which was to last over a thousand years until the renaissance. In this mental climate it would 
have been extraordinary had there been any outstanding contributions to medicine. The only name of importance is that of Paul of Aegina, who lived from A.D. 625-690. He was the last of the Greek eclectics, and his emphasis that his work is not original but that of a mere scribe penning the thoughts of the masters is a sign of the times. He has nothing much to add to his predecessors; again he emphasizes the importance of dentition in convulsions, and he tends to minimize the importance of epilepsy in children. He recommends attention to diet and also the changing of a wet nurse in cases of infantile convulsions. Here he foreshadows views on the dangers of breast milk which are carried to fantastic extremes in the eighteenth century.

\section{Istam}

The Eastern Empire was also subject to repeated attacks, but while that of the west was attacked by northern barbarians who became Christians in the process, that of the east was attacked by Mohammedans who developed an important religion and culture of their own. Moreover, the religious tolerance of their régime attracted many persecuted Christians from the west, although admittedly, by the simple expedient of a tax, large numbers were enticed into the fold of Islam. The Arabian school of medicine which here grew up became the most enlightened of its time, and two Persians are noteworthy, Rhazes in the ninth century, and Avicenna in the tenth.

Rhazes. Rhazes was the first to devote an entire treatise to the diseases of children and his writings were still quoted as authoritative in the fifteenth and sixteenth centuries. A beautiful vellum-bound copy of a Latin translation of his works, printed in Venice in 1508, is to be found in the Library of the Royal Faculty of Physicians and Surgeons in Glasgow. The treatise 'De egritudinibus puerorum' is quite short, and the chapter 'De epilepsia puerorum' is but a paragraph of Hippocratic orthodoxy. The next chapter, also quite short, is entitled 'De quadam passione quae dicitur mater puerorum.' This is the first mention of a strange term which was later used frequently for anything from epilepsy to ' night-terrors.' In Arabian medicine it appeared to mean convulsions as opposed to epilepsy. Rhazes cites the usual causes of infantile convulsions as the cause of mater puerorum. Later it appears to mean the same as epilepsy (Mercuriale and Roelans), while later still it was used more in the sense of 'night-terrors' in children and globus hystericus in adults. Hence 'King Lear' (Act 2, scene 4):

' $O$ ! how this mother swells up toward my heart;

Hysterica passio! down, thou climbing sorrow !'

Avicema. Avicenna, more famous as a philosopher though renowned as a physician as well, wrote largely of infant hygiene in 'Canticum de
Medicina.' In 'Canonis Medicinae' he lists the diseases of infants with little more than a statement of their occurrence, and advocates most drastic remedies such as bleeding and cupping, all directed at the unfortunate wet-nurse. He attributes the convulsions of dentition to fermentation in the gut and, of course, quotes Hippocrates.

\section{From the Dark Ages to the Remaissance}

The dark ages which followed added little to medical knowledge although the famous school of Salerno in the ninth century and that of Montpellier in the twelfth may be mentioned. It was the invention of the printing press in the middle of the fifteenth century that paved the way for the renaissance with which our modern history begins. The change in mental outlook which characterizes this period was determined by the diminishing authority of the church and the increasing authority of science. Temporal authority was now vested in the state, with a result that the culture of the period was more lay than clerical and, moreover, this lay culture was less subject to supervision and direction by the state than that of the middle ages had been by the church. The authority of science however, came much later than the rejection of the authority of the church; there was nothing scientific in the Italian renaissance. The advance of medicine therefore lagged rather behind, and it need not surprise us to find that the earlier works printed have much in common with that of the Greek eclectics and tend to be commentaries upon the Greek and Arabian schools of medicine but more enlightened commentaries perhaps. Three paediatric incunabula of this period are worth a more detailed study; the first by Paolo Bagellardus, the second by Bartholomaeus Metlinger, and the third by Cornelius Roelans. One may also mention an anonymous little book which was often quoted by Roelans and is attributed by Sudhoff to the twelfth century, named 'Diseases of Children Still in the Cradle.' This is entirely therapeutic and recommends for epilepsy peony grass and the curdled milk of a hare.

Bagellardus. Bagellardus was the author of the first printed text-book of paediatrics, entitled 'Libellus de egritunibus infantum' and dated 1472. The first part is devoted to child care and the second to diseases, in which he treats of epilepsy and convulsions of children. On epilepsy he cites both Hippocrates and Avicenna and emphasizes its danger at an early age: 'If it happen at birth, it is not to be cured, or scarcely ever.' In nurselings the treatment is directed at the unfortunate nurse, and the list of dietary restrictions to be imposed upon her would daunt the most altruistic of souls. For older sufferers the materia medica is as picturesque as ever and ranges from the mere suspension of an emerald round the neck to the drinking of the dust (sic) of a burnt 'prickly pig.' It is hard to see in what way convulsions should differ from epilepsy, but it would seem from the short description he 
gives of convulsions that these were attacks of rigidity of even opisthotonus rather than clonic convulsions. The pathogenesis is Hippocratic but the treatment dramatic. 'Yet I know from experience that I have seen many infants so stiff that they could not be bent upward or downward, who, by the mere application on the spondyles of the neck of oil of white lilies or wet hyssop, are relieved and cured by the favour of the Lord from such a contraction.'

Metlinger. The next year saw the publication of another paediatric treatise but this time in the vernacular. Metlinger wrote 'Ein Regiment der jungen Kinder' with the same respectful obeisance to the classic authorities demanded by custom but the obeisance is perhaps a little more formal and even casual. In the section devoted to disease he deals only with convulsions and although there is much of the familiar galenical therapeutics a breath of realism pervades the whole chapter. "It should be known that when convulsions affect a child soon after birth it generally dies. My advice is to protect the children with the help of God. Children may die from this but one should protect those that come later.' 'It is advised that the nursing woman behave herself, avoid sin, avoid eating apples, be clean, and not give the child too much at a nursing but little and often.'

Roelans. Cornelius Roelans is the author of a rare incunabulum which was unknown until exhumed by Sudhoff. An almost identical text, however, was published a hundred years later by Sebastian of Austria under his own name. Roelans' book has no title page but begins with a preface in which he modestly styles himself 'aggregator' or compiler. He cites a formidable array of authorities and lists fifty-two diseases in descending order from head to foot. He also deals with both epilepsy and 'spasms.' If any authorities preponderate in his compilation it is perhaps those of the Arabian school, Avicenna and Rhazes.

\section{The Sixteenth Century}

Guillaume de Baillon. The sixteenth century is of much more interest to the paediatric historian and among a galaxy of names who contributed to the advance of medicine at that time, one, Guillaume de Baillou or Gulielmus Ballonius, wrote on convulsions. He was the first to describe whoopingcough and the first epidemiologist of modern times. $\mathrm{He}$ is also author of one of the first medical dictionaries. Although he wrote towards the end of the sixteenth century, his works were published only some considerable time after his death. In 'De Convulsionibus,' written in 1587, we have the same constant reference to the ancient masters, while a combination of the view held by Hippocrates that the nasal discharge of coryza, or pituita, comes directly from the brain, with that of the cerebral origin of convulsions, leads rather interestingly to a suggestion of the pathological basis for the association of convulsions with respiratory infections.
Lesser Sixteenth-century manes. Also to this period belong Sebastianus Austrius, who plagiarized the works of Cornelius Roelans, Hieronymus Mercurialis, and Scévole de Ste. Marthe. Of Sebastian of Austria, although his works were republished a hundred years later interlarded with prolix commentaries by Nicolas Fontanus and therefore presumably regarded as of some importance, little more need be said; the last word is with the masters. Mercurialis, writing towards the end of the century, shows more originality of thought but with no particular reference to convulsions. Scévole de Ste. Marthe might also be passed over but for the remarkable form in which his treatise on children, 'Paedotrophia,' was written. A Latin epic upon the care of children would seem to be in a strange medium. More remarkable still is its apparent popularity at this time. It was twice translated into English in verse. The sole contribution to the study of convulsions that he makes is the elegant presentation of an inelegant remedy, namely, the powdered ash of human skull.

Thomas Phayer. The sixteenth century also saw the publication of the first book on the diseases of children written in English. The earliest edition extant of 'The boke of children' by Thomas Phayer or Phaer is dated 1545 (the edition consulted, 1546). The fame of Thomas Phayer as a lawyer and a physician was almost eclipsed by his renown as a poet but his medical works nevertheless occupied an important place in the medical literature for the next half century. He devoted one chapter to the "falling-evil called in the greek tongue epilepsia.' As to etiology he states that it is 'sometime by nature received of the parents, and that it is impossible or difficile to cure, sometime by evil and unwholesome diet, whereby there is engendered many cold and moist humours in the brain.' Otherwise he is largely concerned with prophylaxis and treatment. For the former he recommends as charms to be hung round the neck, ' mistletoe of the oak taken in the month of March, and the moon decreasing' and 'the stone that is found in the belly of the young swallow being the first brood of the dame.' In his therapeutics one feels that the poet has as much to say as the physician: one should give with water and honey, the 'maw of leveret,' powdered root of peony, or 'the purple violet that creepeth on the ground in gardens and is called in English, " heartsease.".

\section{The Seventeenth Century}

On the whole the sixteenth century was more occupied with theology than with science. In medicine there was little more than some crude theorizing and meagre observation. The scientific awakening that followed the religious liberation of the renaissance was largely of the seventeenth century, culminating with the publication of Newton's 'Principia' in 1687. Réné Descartes, who is regarded as the founder of modern philosophy, also contributed to modern science 
and in particular to physiology. It is as a philosopher, however, that he has had most influence on medicine and science in general. His break with the scholasticism of the past and his examination de novo of the problem of existence paved the way for a rational investigation of the phenomenal world.

The great advances in every direction of human activity during the seventeenth century permit only of passing reference. The names of Kepler, Galileo, and Newton in science, Descartes, Hobbes, Spinoza, and Locke in philosophy, and Sydenham, Harvey, and Glisson in medicine are eloquent of the greatness of this period. Of those concerned with children in general and convulsions in particular, a more detailed consideration may be of interest. Nicolas Fontanus may be dismissed as belonging at heart to a former century. Similarly J. Starsmare whose 'Children's Diseases' published anonymously in 1664 contains nothing new in the conception of convulsions except an ill-defined relationship to the phases of the moon.

Robert Pemmell. Robert Pemmell, a practitioner in Cranebrook in Kent, was the author, a hundred years after Phayer, of the second book on diseases in children published in English. The full title of this book, including as it does an apologia, is worthy of reproduction. 'De Morbis Puerorum, or a Treatise of the Diseases of Children with Their Causes; Signs, Prognosticks, and Cures, for the benefit of such as do not understand the Latin Tongue, and very useful for all such as are Housekeepers and have Children.' In his chapter on 'The Falling Sickness or Convulsion' he does not differentiate between epilepsy and convulsions and lists among the possible causes, 'corruption' of the milk "which does often happen when the nurse is of ill complexion,' also worms, smallpox, measles, or other fevers. Some cases may be hereditary or due to 'vehement pains of the teeth,' 'sudden fears,' or a thrashing. Of more interest are his comments upon phlegm (presumably upper respiratory infection) as a cause. 'Some will have phlegm to be the cause of Falling Sickness; but if it were so, then why might not old men (whose brains are phlegmatic) have the Falling Sickness . . . : Therefore the Falling Sickness doth not proceed from phlegm, but rather from an occult and sharp quality, which doth oppress the membranes of the brain. For although children do abound with phlegm (from whence suffocating rheums and other diseases be bred) yet doth not the Falling Sickness follow except there be some venomous and corrupt vapour joined therewith.'

There follow also a few pertinent remarks in the chapter upon dentition, where he quotes Hippocrates as authority for citing teething as a cause of convulsions. He reiterates the danger of this period and à propos lancing the gums he is "confident that the want hereof doth occasion the death of many a child.'
Thomas Wilis. In 1667 Thomas Willis, the celebrated author of 'Cerebri Anatome,' wrote at some length upon the subject of convulsions. Here for the first time we have a logical approach to the problem. He deals largely with epilepsy but comments that in children the term 'convulsion" is usually employed. To convulsions in childhood he devotes a separate chapter. Epilepsy may be hereditary or acquired, primary or sympathetic. It is primary when the brain is first affected and sympathetic when the brain is drawn into sympathy with other parts of the body such as the stomach, spleen, uterus, and intestines. He also differentiates between what we would term grand mal and petit mal. The immediate cause of epilepsy he gives as an 'inordinate motion of the spirits in the brain.'

He finds convulsions in children to be most common in the first month of life and during dentition. The prognosis is by far the worst in the newborn. He distinguishes two kinds of convulsion in children. The first might be called toxic, and he includes those caused by excessive heat or cold, dietary excesses, changes of air and by the sudden disappearance of an exanthem. The second might be termed reflex and he attributes these to irritation of peripheral nerves such as by milk curdled in the stomach, worms or teething. He describes in some detail how dentition causes convulsions reflexly. The growing tooth causes pressure on the fifth nerve and so presumably stimulates the brain. With regard to treatment, he advocates lancing of the gums, or 'friction' and also purging, enemata, bleeding, and vesicants. His appreciation of the value of post-mortem examination and his truly scientific approach to the interpretation of his results are a notable advance.

Walter Harris. 1689 is an important landmark in the history of paediatrics. So far there had been no generally accepted text-book of paediatrics written by a physician. Walter Harris supplied this want, and his book 'De Morbis Acutis Infantum' became the standard work on the subject and remained so, being translated into English in 1742, until the appearance of Underwood's treatise in 1789. As the relationship of teething to convulsions will play an important part in tracing the modern views on convulsions from this time onwards, it is of interest to quote Harris verbatim (Martyn's translation): 'Of all the Disorders which threaten the Lives of Infants, there is none that is wont to produce so many grievous Symptoms as a difficult and laborious Breeding of Teeth.' Apart from dentition he makes no reference to etiological factors in convulsions except one that he styles hereditary and which is apparently limited to the newborn. He attributes this to a 'Foulness contracted in the Womb.'

\section{The Eighteenth Century}

The eighteenth century which virtually begins in the final decades of the seventeenth, was a period of relief and escape; relief from the strain of a 
mysterious universe. Pope's oft quoted couplet well illustrates the feeling of the times:

-Nature and Nature's laws lay hid in night:

God said, Let Newton be ! and all was light !'

To quote Basil Willey, 'Nature's laws had been explained by the New Philosophy; sanity, culture, and civilization had revived; and at last, across the gulf of the monkish and deluded past, one could salute the ancients from an eminence perhaps as lofty as their own.' The tempo of advance in science and medicine was now increasing. Observation and experiment was laying the foundation of modern medicine. One has only to mention some of the names, Linnaeus, Rutherford, Priestley, John and William Hunter, Auenbrugger, Heberden, Pott, to illustrate the greatness of this century.

Underwood. It is thus with rather a sense of disappointment that one reads the chapter on convulsions in Underwood's 'A Treatise on the Diseases of Children' published in 1789. For Underwood's text-book remained the authoritative work on the subject for over sixty years and is certainly in style and mental approach, the forerunner of the modern scientific text-book. He first describes convulsions as being of two kinds, symptomatic and idiopathic, the latter being due to a morbid affection of the brain. He doubts himself, however, the validity of this distinction and is inclined to call all convulsions, in infancy at least, symptomatic as one can usually find in every case, a cause. Of these causes the most important are teething and alimentary irritation, and he instances indigestibility of food and intestincal parasites and even ' wind' as potent causes of convulsions. In addition he attributes some cases to a dângerous quality of the breast milk which can be caused apparently by emotional changes in the mother or wet-nurse and he gives an example of a woman who had a fright and who thereupon suckled her child which straightway had a fit. For treatment he recommends purges, enemata, and bleeding.

Bames. Another famous work is Baumes' 'Traité des Convulsions dans l'Enfance' written in 1805. He believed convulsions to be largely constitutional and attributable to 'les facheuses impressions de l'air.' The 'curdled breast milk' is given great prominence, and he instances the child of a colleague who had a convulsion after sucking at the breast of its nurse who had immediately before been very angry. The choicest anecdote is that of a woman who, knowing apparently of the dangers to her child, after having lost her temper suckled her little dog; the dog at once had a fit. All views are carried to extremes and he described convulsions of such violence as to break bones and lacerate tissues. He treats at great length of diet and hygiene as prophylactic measures. He also lists every known helminth as a cause of convulsions and would differentiate between the syndromes produced by each worm.
The Early Nineteenth Cemtury

Jom Burss. John Burns included a chapter on diseases of children in his text-book of midwifery and gynaecology in 1814. He classified convulsions into those due to a primary affection of the brain, e.g. hydrocephalus, and those in which the affection of the brain is 'in sympathy' with some other organ in a state of irritation. The causes of the 'irritation' are the usual ones, and he includes Baumes' impure air. He also includes trismus of the newborn as due to constipation though he states that others believe it to be due to an infection of the umbilicus.

John Clarke. The next important contribution was that of John Clarke in 1814. His 'Commentaries on some of the most important diseases of children' contains the first clear-cut clinical description of tetany including laryngismus stridulus, carpo-pedal spasm, and convulsions. Although no etiological basis could be given for this condition, the separation of one group of convulsions on clinical grounds marked an important step in their classification. In addition there is a long chapter on infantile convulsions. He comments upon the large number of children shown as dying of convulsions in the London Bills of Mortality, but points out that terminal convulsions are not uncommon in infancy and that the probability is that a large number of deaths are so recorded whereas the underlying primary condition is not noted. Thus we have two clear-cut classes of convulsion separated from the main body, the convulsions of tetany (though not, in fact so-called until named by Corvisart) and the non-specific terminal convulsions.

John North. In 1826 John North published his - Practical observations on the convulsions of infants.' He lists as the main causes of convulsions ' large or enlarging heads,' 'rachitis,' and 'hereditary predisposition,' and this is the first record that I have found of rickets being a cause of convulsions. However the fundamental cause is the greater sensitivity of children. This sensitivity is apparently greater in the tropics and he quotes a colleague, one Dr. Hillary, who 'observes that the children in the Isle of Barbadoes are so irritable that they are thrown into a convulsion at the slightest noise.' Loss of consciousness is not essential to the diagnosis of convulsions, which he differentiates from epilepsy in which loss of consciousness is the ruke. From this he goes on to the pathological fantasy that epilepsy is derived from the brain and its membranes whereas simple convulsions come from the cord. Simple convulsions he divides into symptomatic and idiopathic though he also doubts the latter. He finds convulsions occur seldom at night, a fact that he attributes to there being fewer stimuli. He comments upon a marked increase in the incidence of convulsions and attributes it to over education. At this time children were given advanced teaching at a very much earlier age than to-day. His causes of the symptomatic convulsions are the usual ones 
such as teething and constipation, though he castigates Baumes for his emphasis on helminths as a cause. He mentions, however, that in Germany the current opinion was that children rarely if ever suffered from the effects of dentition. He also describes carpo-pedal spasm as a prodromal sign of convulsions. He perpetuates the idea of harmful breast milk as a cause but the suggestion that suckling during menstruation may cause convulsions, he tells us, "requires no further notice than the mention of its absurdity. In addition he derides the common superstition in nurses that constipation in an infant denotes strength and advocates a purgative in all cases. He has two new etiological factors for convulsions of the newborn, retention of meconium and the shining of too bright a light on the child immediately after birth.

\section{The Modern Period}

In the next thirty years such text-books as those of Evanson and Maunsell in Dublin, and Radcliffe continue in much the same vein. Towards the end of the nineteenth century, however, the tempo of scientific advancement was accelerating to reach the breathtaking speed of the present day and the greatness of the fin-de-siècle may properly be taken as the beginning of the modern period.

Kussmaul and Tenner. In 1859 Kussmaul and Tenner described some important observations on the pathogenesis of convulsions. As a result of various animal experiments to determine the relationship between haemorrhage and convulsions, they concluded that convulsions might be produced by (1) rapid loss of blood, (2) sudden stoppage of flow of arterial blood to the brain such as produced by ligature, spasm, inflammation, or excitement, (3) rapid transformation of arterial blood to venous as in asphyxia, which, of course, would explain the association of convulsions with laryngismus stridulus. They further conclude that some cases of epilepsy may be caused in this way.

Trousseau. In 1862 Trousseau published his - Clinique Médicale de l'Hôtel-Dieu de Paris.' Although he devotes a great deal of space to the consideration of tetany, including of course a detailed description of the sign that goes by his name, he does not relate it in any way to infantile convulsions. Indeed there is a lot that is already very familiar in his description of infantile convulsions. He classifies them as idiopathic or symptomatic, the former showing no discernible pathological chanfe in the central nervous system except some congestion which he regards as secondary. Otherwise we have the predisposing factors of heredity, underfeeding, haemorrhage, high fever, exposure to cold or emotional upsets, and above all, local irritation including ill-fitting clothes and sinapism. The symptomatic convulsions are due either to demonstrable disease of the central nervous system or in sympathy with disease in some other part of the body such as the exanthemata.
Hughlings Jackson. The most impressive article of this period is one by Hughlings Jackson that appeared in Reynold's 'System of Medicine ' in 1868. Jackson emphasises that a convulsion is a symptom and not a disease and this, though apparently simple, is a most important advance in our understanding of the problem. For consideration he divides convulsions into those affecting children up to seven years of age and those affecting children over seven.

On convulsions in the former age group he says they differ from adult convulsions only in the immaturity of the nervous system, and he considers them as equivalent to delirium in adults. He cites cerebral haemorrhage as a cause of convulsions in the newborn. He condemns the use of the terms 'essential' or 'idiopathic " convulsions or eclampsia, for he believes these convulsions to differ in no essential from epilepsy. He describes crowing and carpo-pedal spasm in convulsions but while he admits that these occur more frequently in rachitic children he includes them with other localizing indications as a manifestation of the site in the brain of the nervous discharge. Hughlings Jackson is of course responsible for the conception of epileptic discharge and that the site of maximal discharge would determine the type of manifestation at the beginning of the attack. This, as Symonds points out, was intended to apply to epilepsy as a whole and not only to traumatic epilepsy which he used however to illustrate his point. It seems particularly unfortunate that the term 'Jacksonian epilepsy ' was used to denote epilepsy arising from a macroscopic pathological focus in the brain when no such restricted concept was intended by Jackson. He was concerned with the localization of the lesion and not with its pathology and would, one feels sure, have agreed that the commonest cause of a Jacksonian attack is idiopathic epilepsy. He next makes the vitally important point that such factors as over-eating, worms, and teething will not produce convulsions in a healthy nervous system. He does not try to differentiate between eclampsia (or idiopathic convulsions of childhood) and epilepsy but points out that many epileptics give a history of convulsions in childhood which had been disregarded. For treatment he condemns the routine use of purges, emetics, and lancing of gums and rather doubtfully allows their use if there is an obvious indication.

Soltmann. The experimental work of Soltmann in 1876-78 is of great importance in the study of convulsions in children. He was the first to approach the problem of the greater susceptibility of children to convulsions experimentally. He demonstrated in animals aged one to ten days, that stimulation of the cortex produced no result whereas there was hyper-excitability of the peripheral nerves. He reckoned the ten days to be the equivalent of six months in man and postulated immaturity of the nervous system with failure of the reflex inhibiting 
motor centre of the brain. This was an important physiological observation but the corollary that any peripheral 'irritation' might therefore be responsible for a convulsion seems decidedly retrograde, particularly in the light of the previous work of Hughlings Jackson. However, Soltmann's views did not pass unchallenged and Fleischmann made the pertinent observation that in burns-an especially striking form of 'peripheral irritation'convulsions did not occur, while Henoch pointed out that the liability of children to convulsions was not limited to the first six months or even the first year of life.

Henoch. Henoch was a pupil of Schönlein and one of the principal German contributors to paediatrics. In his 'Lectures on Children's Diseases' he discusses the pathology of convulsions in relation to the recent work of Kussmaul and Tenner and also suggests head injury as an occasional cause with extravasation of blood into the medulla. In repeated convulsions, however, he recommends examining the bones for ' according to my experience, the tendency to convulsions is favoured by nothing so strongly as rickets.' In children aged six months to three years with convulsions, rickets was usually more or less marked and laryngismus either concomitant or alternating with the convulsion, almost constant. He considers rickets to be more important than dentition in this connexion. In reflex causes he places irritation of the gut first, though he had seen no case that could be attributable to worms. In convulsions associated with a febrile illness he suggests an analogy with the rigor of an adult: In addition he points out that any fit may be the first sign of epilepsy.

Gowers. Gowers in 1893 defines epilepsy as the result of the tendency of the brain to discharge, and separates other convulsions arising from causes other than primary states of the brain, under the head of eclampsia though he specifically excludes from this the "single fit at the onset of an acute infection or in consequence of an indigestible meal.' $\mathrm{He}$ attributes the special liability of children to eclampsia to the non-myelinated state of the nerve fibres and to the fact that the lower centres in childhood are further advanced than the higher controlled centres. However, he goes on to say that the next most potent cause is rickets (then of course regarded as a 'constitutional' disease of unknown etiology) and attributes to rickets the majority of so-called teething convulsions. He notes the association of carpo-pedal spasm and laryngismus with rachitic convulsions. He accepts, however, gastro-intestinal irritation by indigestible food or worms as a cause.

Paul Simon. Paul Simon, writing in Grancher, Comby, and Marfan's text-book in 1898, also criticizes Soltmann's theory on the ground that as all children do not have convulsions though they are all exposed to some degree of the peripheral irritation that should cause them, there must be some specific predisposition. This he suggests may be hereditary or due to debility especially of the nervous system as in prematurity, artificial feeding, haemorrhage, intestinal flux, congenital syphilis, and rickets. He denies that teething is ever a cause of convulsions but cites temper at being thwarted as one.

The Beginnings of Real Inquiry into Infantile Convulsions and Epilepsy

Now for the first time there begins a real enquiry into the prognosis of infantile convulsions and their relation, if any, to epilepsy. In 1843 Rilliet and Barthez put the question without coming to any very definite conclusion. Infantile convulsions may or may not be epileptic and time alone will tell. Bouchut in 1855 believed all infantile convulsions to be incidental and with a good prognosis. So also D'Espine and Picot (1877), who denied the relation of eclampsia (or infantile convulsions) to epilepsy, terming the former ' un accident éphémère.' On the other hand Comby in 1897 and Féré in the same year called all infantile convulsions epileptic. They both stressed the importance of heredity as an etiological factor, and Comby, while accepting as precipitating factors dyspepsia, gastro-enteritis, rickets, and eruptive fevers and pneumonia, doubted the importance of dentition. In America, Walton and Carter (1891) joined the optimists and concluded that 'epileptics are at least no more likely to have had infantile convulsions and conversely a child suffering from infantile convulsions is no more likely to suffer from epilepsy in life after a period of immunity has removed the case from the class of epilepsy beginning in infancy and becoming continuous.'

Thus we come to the twentieth century and the present day, a description of which is beyond the compass of this paper. Beginning with Hochsinger, and Thiemich, with contributions from Husler, Patrick and Levy, Graham, Herlitz, Lennox, Peterman, and Thom, the study of convulsions in infancy and childhood has been established upon a logical basis, and if there are still problems to solve, at least a great deal of the ground has been cleared.

I record with pleasure my gratitude to Prof. Stanley Graham for valuable criticism and advice; I am also indebted to the Librarians of the Royal Faculty of Physicians and Surgeons and of the Royal Society of Medicine for much searching in their respective basements.

General References:

\section{BIBLIOGRAPHY}

Fisher, H. A. L. (1944). A History of Europe. Edward Arnold and Co. London.

Garrison, F. H. (1923). History of Pediatrics in Abt's Pediatrics. W. B. Saunders and Co. Philadelphia and London.

(1929). An Introduction to the History of Medicine. W. B. Saunders and Co. Philadelphia and London. 
Russell, B. (1946). History of Western Philosophy. George Allen and Unwin. London.

Still, G. F. (1931). The History of Paediatrics. Oxford University Press. London.

Aristotle. History of Animals. Translated by $\mathbf{R}$. Cresswell (1862). H. G. Bohn. London.

Austrius, S. Text in Fontanus (1641).

Avicenna. A Treatise on the Canon of Medicine of Avicenna, incorporating a translation of the first book by $O$. C. Gruner. (1930.) Luzac and Co. London.

Ballonius, G. (1762). Opera Omnia, lib. 1. Fratres de Tournes. Geneva.

Bagellardus, P. (1472). Libellus de egritudinibus infantum Padua. Cited Sudhoff (1909). Text in Ruhräh (1925).

Baumes, J. -B. T. (1805). Traité des convulsions dans lenfance. Méquignon. Paris.

Bouchut, E. (1855). Practical Treatise on the Diseases of Children and Infants at the Breast. Translated by P. H. Bird. London.

Burns. J. (1814). Principles of Midwifery including the Diseases of Women and Children. Longman, Hurst, Rees, Orme, and Brown. London.

Celsus, A. C. De Re Medicina. Translated by J. Grieve (1756). London.

Clarke, J. (1815). Commentaries on some of the most important Diseases of Children. London.

Comby, J. (1897). Stedman's XXth Century Practice. Vol. XII. Sampson Low, Marston and Co. London.

d'Espine, A., and Picot, C. (1877). Manuel Pratique des Maladies de I'Enfance. Baillière et Fils. Paris.

Evanson, R. T., and Maunsell, H. (1847). A Practical Treatise on the Management and Diseases of Children. 5th Edition. Fannin and Co. Dublin.

Fère, Ch. (1897). Stedman's XXth Century Practice. Vol. X. Sampson Low, Marston and Co. London.

- (1890). Les Epilepsies et les Epileptiques. Paris.

Finlayson, J. (1893). Ancient Egyptian Medicine. Glasgow.

Fleischmann, cited Thiemich (no reference).

Fontanus, N. (1641). Commentarius in Sebastianus Austrium De Puerorum Morbis. Amsterdam.

Galen, C. De Sanitate Tuenda: Medicorum Graecorum Opera quae extant. Vol. 6. Ed. D. C. G. Kühn (1823). Leipzig.

- On Medical Experience. Translated by R. Walzer (1944). Oxford University Press. London.

Gowers, W. R. (1893). A Manual of Diseases of the Nervous System. J. A. Churchill. London.

Harris, W. (1689). De Morbis Acutum Infantum. London.

Henoch, E. (1893). Vorlesung uber Kinderkrankheiten. Berlin.
Hippocrates. Genuine Works translated from the Greek with a preliminary Discourse and Annotations by F. Adams (1819). Sydenham Society. London. Jackson, Hughlings (1868). Convulsions in Childhood. In Reynold's System of Medicine. Macmillan and Co. London. (1890). Brit. med. J., 1, 703, 765, 821.

Kussmaul, A., and Tenner, A. (1859). The Nature and Origin of Epileptiform Convulsions. Translated by E. Bronner for the Sydenham Society. London.

Mercuriale, H. (1584). De Morbis Puerorum. Basileae.

Metlinger, B. (1473). Ein Regiment der jungen Kinder. Cited by Sudhoff. Text in Ruhräh (1925).

North, J. (1826). Practical Observations on the Convulsions of Infants. Burgess and Hill. London.

Paul of Aegina. Works. Translated by F. Adams (1834-1847) for the Sydenham Society. London.

Pemmell, R. (1653). De Morbis Puerorum. Printed by F. Legatt for Philemon Stephens at the Guilded Lion in Paul's Churchyard, London.

Radcliffe, C. B. (1858). Epilepsy and other convulsive affections. Churchill. London.

Rhazes. Opera. A Latin translation printed in Venice in 1508 .

Roelans, C. Cited by Ruhräh. Still. and Sudhoff.

Ruhräh, J. (1925). Pediatrics of the Past. P. B. Hoeber. New York.

Ste Marthe, S. de (1797). Paedotrophia, or the Art of Nursing and Rearing Children. Translated by H. W. Tytler. Nichols. London.

Soltmann. O. (1876). Jb. Kinderheilk., 9, 106.

- (1877). Ibid., 11, 101.

- (1878). Ibid., 12, 1.

Soranus of Ephesus. Cited by Garrison and Still.

Starsmare, J. (1664). Paidon Nosimata or Children's Diseases. Cited by Still.

Sudhoff, K. (1909). 'Die Schrift des Cornelius Roelans von Mecheln über Kinderkrankheiten' Janus, 14, 467.

Symonds, C. P. (1948). 'Epilepsy.' Brit. med. J., 1, 533.

Thiemich, M. In Vol. II of Handbuch der Kinderheilkunde by Pfaundler and Schlossmann (1806). F. C. W. Vogel. Leipzig.

Trousseau, A. (1862). Clinique Médicale de l'Hôtel-Dieu de Paris, Vol. 2. Baillière et Fils. Paris.

Underwood, M. (1789). A Treatise on the Diseases of Children. J. Mathews. London.

Walton, G. L.. and Carter, C. F. (1891). On the etiology of epilepsy with special reference to the connexion between epilepsy and infantile convulsions. Boston med. and surg. J., 125, 485.

Willey, B. (1946). The Eighteenth Century Background. Chatto and Windus. London.

Willis, T. (1667). Pathologiae Cerebri et Nervosi Generis, Specimin in quo agitur de Morbis convulsivis et de Scorbuto. Elsevir. Oxford. 